27 Hisamichi S, Sugawara N. Mass screening for gastric cancer by $x$-ray examination. Fpn f Clin Oncol 1984;14:211-23.

28 Itoh $H$, Oohata $Y$, Nakamura $K$, Nagata T, Mibu R, Nakagama F. Complete ten-year postgastrectomy follow-up of early gastric cancer. Am f Surg 1989:158:14-6.

29 Maruyama K. The most important prognostic factors for gastric cancer patients. A study using univariate and multivariate analyses. Scand $f$ Gastroenterol 1987;22(suppl 133):63-8.

30 Kodama Y, Sugimachi K, Socjima K, Matsusaka T, Inokuchi K. Evaluation of extensive lymph node dissection for carcinoma of the stomach. World $\mathcal{F}$ Surg 1981;5:241-8.

31 Siewert JR, Bottcher K, Roder JD, Busch R, Hermanek P, Meyer HJ, and the German Gastric Carcinoma Study Group. Prognostic relevance of systematic lymph node dissection in gastric carcinoma. Br f Surg 1993;80:1015-8.

32 Cuschieri A. Gastrectomy for gastric cancer: definitions and objectives. Brf Surg 1986;73:513-4.

33 Akoh JA, Sedgwick DM, Macintyre IMC. Improving results in the treatment of gastric cancer: an 11-year audit. Br $\mathcal{Y}$ Surg 1991;78:349-51.

34 Irving TT, Bridger JE. Gastric cancer. An audit of 122 consecutive cases and

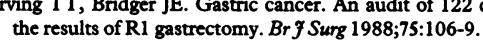

35 Inberg MV, Vuori J, Viikari SJ. Carcinoma of the stomach. A follow up study of 1963 patients. Acta Chir Scand 1972;138:195-201.

36 Nielsen SA, Amdrup E, Christiansen P, Fenger C, Jensen HE, Lindskov J, et al. Carcinoma of the stomach. An analysis of 385 cases treated 1955-1964. Acta Chir Scand 1974; 140:313-20.

37 Svennevig JL, Nysted A. Carcinoma of the stomach. A ten year material. Acta Chir Scand 1976;142:78-86.

38 Buchhloltz TW, Welch CE, Malt RA. Clinical correlates of resectability and survival in gastric carcinoma. Ann Surg 1978;188:711-5.
39 Adashek K, Sanger J, Longmire WP Jr. Cancer of the stomach. Review of consecutive 10 year intervals. Ann Surg 1979;189:6-10.

40 Shiu MH, Papacristou DN, Kosloff C, Eliopoulos G. Selection of operative procedure for carcinoma of mid stomach. Ann Surg 1980;192:730-7.

41 Yan $C$, Brooks $J R$. Surgical management of gastric adenocarcinoma. Am F Surg 1985;149:771-4.

42 Sjostedt S, Pieper R. Gastric cancer. Factors influencing long term survival and post-operative mortality. Acta Chir Scand Suppl 1986;530:25-9.

43 Hartley LC, Evans E, Windsor CJ. Factors influencing prognosis in gastric cancer. Aust NZ F Surg 1987;57:5-9.

44 Meyers WC, Damiano R, Postlethwait RW, Rotolo FS. Adenocarcinoma of the stomach: changing patterns over the last 4 decades. Ann Sung 1987;205: $1-8$.

45 Lindahl AK, Harbitz TB, Liavag I. The surgical treatment of gastric cancer: a retrospective study with special reference to total gastrectomy. Eur f Surg Oncol 1988;14:55-62.

46 Day NE. Quantitative approaches to the evaluation of screening programs. World f Surg 1989;13:3-8.

47 Neugut AI, Pita S. Role of sigmoidoscopy in screening for colorectal cancer: critical review. Gastroenterology 1988;95:492-9.

48 Hisamichi S. Screening for gastric cancer. World ₹ Surg 1989;13:31-7.

49 Sue-Ling HM, Martin I, Griffith J, Ward DC, Quirke P, Johnston D, et al. Early gastric cancer: 46 patients treated in one surgical department. Gut 1992;33:1318-22.

50 Sue-Ling HM, Young S, Griffith J, Selby P, Johnston D. Quality of life after radical (R2) gastrectomy for gastric cancer. Gut 1993;34(suppl 1):S15.

(Accepted 2 fuly 1993)

\title{
Road traffic and adverse effects on respiratory health in children
}

\author{
Matthias Wjst, Peter Reitmeir, Sigrid Dold, Andrea Wulff, Thomas Nicolai, \\ Edith Freifrau von Loeffelholz-Colberg, Erika von Mutius
}

\begin{abstract}
GSF-Forschungszentrum fïr Unwelt und Gesundheit, Institut für Medizinische Informatik und Systemforschung, D-85758 Oberschleissheim, Germany

Matthias Wjst, research fellow

Peter Reitmeir, statistician Andrea Wulff, research assistant

Institut für Umwelthygiene und Toxikologie, Technische Universităt München,

D-80636 Munich,

Germany

Sigrid Dold, research fellow
\end{abstract}

Dr von Haunersche Kinderklinik, LudwigMaximilians-Universităt Munchen, D-80337 Munich, Germany Thomas Nicolai, paediatrician

Erika von Mutius, paediatrician

\section{Stadtische}

Gesundheitsbehörde D-80335 Munich,

Germany

Edith Freifrau von

Loeffelholz-Colberg

director

Correspondence to:

Dr M Wjst,

GSF-Forschungszentrum

für Umwelt und Gesundheit,

Institut für Epidemiologie,

PO Box 1129

D-85758 Oberschleissheim, Germany.

BMY 1993;307:596-600
Abstract

Objectives-To examine whether road traffic in a big city has a direct effect on pulmonary function and respiratory symptoms in children.

Design-Cross sectional study.

Setting-Of all 7445 fourth grade children (aged 911 years) in Munich, 6537 were examined. Of the children with German nationality and the same residence during the past five years and known exposure data, 4678 questionnaires and 4320 pulmonary function tests could be analysed.

Main outcome measures-Variables of pulmonary function by forced expiration and respiratory symptoms reported in a questionnaire; census data on car trafific collected in the school district.

Results-Density of car trafic ranged from 7000 to 125000 cars per 24 hours. Multiple regression analysis of peak expiratory flow showed a significant decrease of $0.71 \%$ (95\% confidence interval $1.08 \%$ to $0.33 \%$ ) per increase of 25000 cars daily passing through the school district on the main road. Maximum expiratory flow when $25 \%$ vital capacity had been expired was decreased by $0.68 \%(1 \cdot 11 \%$ to $0 \cdot 25 \%$ ). In contrast, response to cold air challenge was not increased. The adjusted odds ratio for the cumulative prevalence of recurrent wheezing with the same exposure was $1.08(1.01$ to $1 \cdot 16)$. Cumulative prevalence of recurrent dyspnoea was increased, with an odds ratio of $1.10(1.00$ to $1 \cdot 20)$. Lifetime prevalence of asthma (odds ratio $1.04 ; 0.89$ to 1.21 ) and recurrent bronchitis $(1.05 ; 0.98$ to 1.12$)$ were not significantly increased.

Conclusions-High rates of road traffic diminish forced expiratory flow and increase respiratory symptoms in children.

\section{Introduction}

The effects of both indoor and outdoor pollutants on health are of great public interest. Several studies have confirmed an association between both outdoor air pollutants ${ }^{1-5}$ and indoor pollutants $s^{6-9}$ and respiratory health. With increasing motorisation throughout the world the emission of potentially hazardous substances is increasing. One main source of outdoor air pollution is road traffic, which produces a mixture of volatile hydrocarbons, airborne particles, nitrogen oxides, and carbon monoxide. ${ }^{11}$ As there are only a few reports of the effects on respiratory health of car exhaust fumes we examined census data on cars in relation to respiratory symptoms and pulmonary function in children. In Munich air pollution is caused primarily by car exhaust fumes and only to a small degree by industry.

\section{Subjects and methods}

STUDY SITE

Munich is $\mathbf{5 3 0}$ metres above sea level in the south of Germany and is the capital of Bavaria. It has a population of 1.27 million (July 1990) in an area of $3104400 \mathrm{~m}^{2} .^{12}$ In 1990 there were 649000 cars registered in Munich. Movements of traffic in the inner city increased by about $40 \%$ between 1970 and 1990 with traffic at the city limits going up by more than $125 \%$. Nearly a million cars pass the city border every day. ${ }^{13}$

Permanent multicomponent air monitoring stations have been installed at a height of 3 metres in the city. During the study the average mean values at the Karlsplatz-Stachus site, where 70000 cars pass by every 24 hours, were $0.148 \mathrm{mg} / \mathrm{m}^{3}$ for nitrogen monoxides, $0.076 \mathrm{mg} / \mathrm{m}^{3}$ for nitrogen dioxides, $4.609 \mathrm{mg} / \mathrm{m}^{3}$ for carbon monoxide, and $0.016 \mathrm{mg} / \mathrm{m}^{3}$ for sulphur dioxide. These figures did not exceed standards for air quality. ${ }^{14}$ To validate further the assessment of exposure, data from more than 250 measurements of nitrogen dioxide distributed over the city measured in 1984-7 15 and of benzene, toluene, hydrocarbons, and ozone measured in $1988^{16}$ were correlated to rates of car traffic. If there was more than one measurement in a single school district the arithmetic mean was taken.

\section{STUDY DESIGN}

This report shows the results of a cross sectional study carried out from 1989 to 1990 on all children in the fourth grade at school (age 9-11 years) in the city of Munich. The main objective of the Munich asthma and 
allergy study was to determine the prevalence of allergic and asthmatic diseases. ${ }^{17}$ As the total sample of children in the fourth grade was used no calculations of sample size were needed. All the parents gave informed and written consent for their children to participate. The study was approved by the ethics committee of the Bayerische Landesärztekammer.

From October 1989 to July 1990 a questionnaire consisting of 58 questions on the allergic and asthmatic symptoms of the child and family was distributed to 7445 children in 118 schools. Data from 6537 were collected. Standardised questions were used to obtain histories of respiratory symptoms and illness as well as demographic data. For asthma the question was "Has a physician ever diagnosed one of the following diseases?" and asthma or recurrent asthmatic or spastic bronchitis was taken for asthma. For a previous diagnosis of croup and allergic rhinitis parents had to check the yes or no boxes. For upper respiratory infections during the past 12 months parents could select fewer than five, five to 10 , more than 10 , or do not know. The point prevalence of common colds at the time of examination was determined by the typical signs of hoarseness or runny nose. Cough was defined as frequent coughing for longer than 14 days or frequent coughing at night without cold or coughing after exercise. For the questions "Has your child's breathing ever been accompanied by wheezing or whistling noises?" and "Did your child ever experience breathlessness without physical exertion?" parents had to select never, once, several times, or do not know.

Schools and field technicians to perform lung function tests on the children were selected in a random order. The children were examined throughout the year except from July to September because of school holidays. Each child was asked about present respiratory illness. Height and weight were measured with clothes but without shoes. Then lung function tests were performed from 8 am to $1 \mathrm{pm}$ by using an electronic spirometer (Pneumoscop II, Jaeger, Würzburg, Germany). Subjects performed forced expiration while sitting and wearing a nose clip. We recorded the forced vital capacity, forced expiratory volume in one second, forced expiratory peak flow rate, and maximal expiratory flow rates when $25 \%, 50 \%$, and $75 \%$ of forced vital capacity had been expired. Forced flow volume tests were performed until three reproducible loops were obtained according to the criteria of the American Thoracic Society. ${ }^{18}$ The best value for each variable was used. All spirometers were calibrated daily. Cold air challenge with air at $-15^{\circ} \mathrm{C}$ was carried out with a respiratory heat exchange system (Jaeger, Würzburg, Germany) as described earlier. ${ }^{18}$ The children hyperventilated cold air supplemented with $5 \%$ carbon dioxide for four minutes at $75 \%$ of their maximum rate of ventilation per minute. Lung function testing was repeated within the next five minutes.

\section{ASSESSMENT OF EXPOSURE}

The city area of Munich is divided into 117 primary school districts. Primary school children attend the school nearest to their home, normally located in the centre of the district.

The mean diameter of the district usually does not exceed $2 \mathrm{~km}$. Census data on car traffic on main streets were obtained by automatic induction loops. Cars on smaller streets were counted over 24 hours and a few over eight hours. Cars were counted on weekdays (Tuesday through to Thursday, except school holidays); the values were updated in 1988 and included more than 600 streets. ${ }^{13}$ Each school district was therefore allocated the street with the highest volume of traffic (fig 1). Two schools were excluded

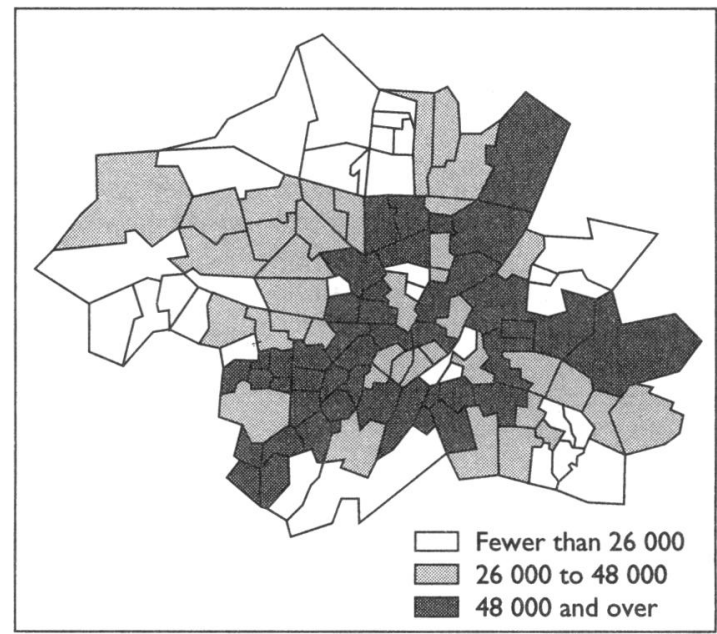

FIG 1-City map of Munich: maximum traffic counts per 24 hours by thirds in school districts

from the analysis because of missing data on exposure and one school because there is no direct school district.

\section{EVALUATION OF EFFECT}

Children with a nationality other than German (1507) were excluded from all the calculations (fig 2). These comprised 451 Turkish, 435 Yugoslavian, and 21 Greek children and 600 of other or unknown nationality. Despite translated versions the foreign questionnaires were often only partially answered.

We also excluded children who had lived for less than five years at their present address (277) because the assessment of exposure would not be clear. Seventy five children had to be excluded because of other missing data. A total of 4678 children therefore remained in the study.

When we analysed pulmonary function in addition to the above criteria the children on whom we had data only from the questionnaire and children with acute respiratory infection at the date of the examination (358) were excluded, so that 4320 subjects remained. The analysis of pulmonary function relied on a multiple regression model. ${ }^{7}$ Each variable of pulmonary function was analysed separately. To determine the effect of road traffic the natural logarithm (ln) of the pulmonary function value was modelled with parental history of asthma, ln (height), ln (weight), month of examination, compliance with test, number of cigarettes smoked at home daily, and indoor use of gas or coal for cooking or heating. School education of parents served as indicator of socioeconomic state. Compliance with the test as judged by the field technicians was added because failure on spirometric tests itself could influence the results by children failing to breathe out to residual volume. ${ }^{19}$ Traffic counts were entered as a continuous variable, and the results were expressed as the effects of an increase of 25000 in the car count in each school district.

Multiple logistic regression was used to estimate the effect of the traffic count on respiratory symptoms while the effects of parental history of asthma, parental school education, number of people in household, use of gas or coal for cooking or heating, month of survey, number of cigarettes smoked at home, and who completed the questionnaire were controlled for. These confounders have been described as relevant in a comparable setting. ${ }^{7}$ Although adjustment for asthma among parents may be considered conservative as some familial aggregation may be due to the parents being exposed to the same pollutant, this variable was included in the models to consider possible overreporting of children's symptoms by parents with a positive respiratory history. 


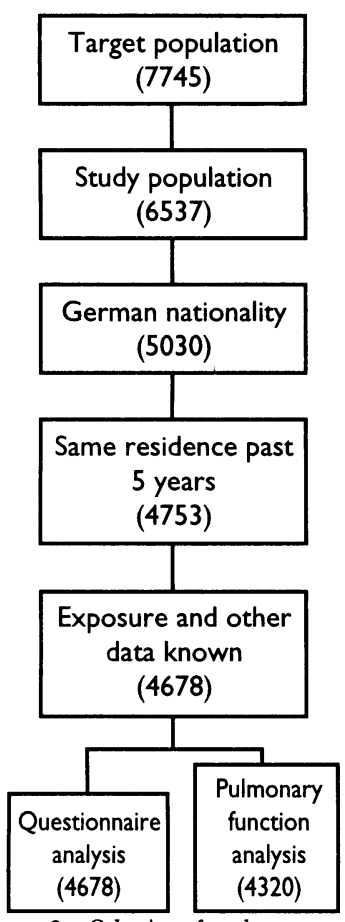

FIG 2-Selection of study population

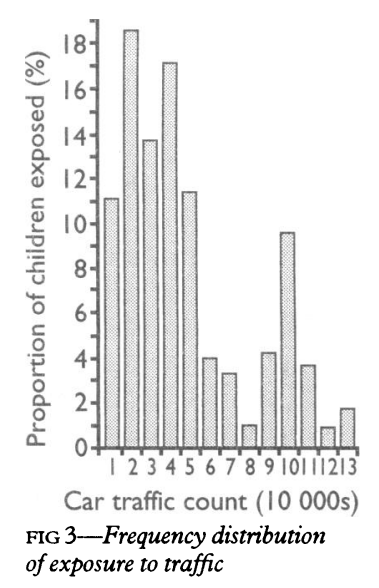

All analyses were done by SAS version 6.07 with the LOGISTIC procedure for symptom analysis and the REG procedure for pulmonary function analysis. ${ }^{29}$

\section{Results}

Table I summarises the characteristics of the study group. The maximum traffic counts in the school districts ranged from 7000 to 125000 cars per 24 hours with a median of 40000 cars per 24 hours (fig 3). With increasing traffic the concentrations of carbon monoxide (Pearson's $r=0.40 ; \mathrm{p}<0.001)$, benzene $(r=$ $0.28 ; \mathrm{p}=0.003)$, hydrocarbons $(r=0.21 ; \mathrm{p}=0.022)$, and toluene $(r=0.18 ; \mathrm{p}=0.048)$ increased but ozone decreased $(r=-0.34 ; \mathrm{p}<0.001)$. Nitrogen dioxide concentration $(r=0.01 ; \mathrm{p}=0.878)$ did not correlate with traffic concentration.

Table II shows the adjusted percentage changes in measurements of pulmonary function with an increase of 25000 cars in the school district. Children had reduced peak expiratory flow rates and maximal expiratory flow rates when $25 \%$ and $50 \%$ of forced vital capacity had been expired. The response to cold air challenge, indicated by absolute or relative change in any of the measured variables, did not increase.

To check if the effect of road traffic occurs mainly in conditions of high exposure, traffic measurements were categorised into thirds. In the lowest third the traffic rate was lower than 26000 cars per 24 hours. The rate in the middle third ranged from 26000 to 48000 , and in the upper third traffic rates were higher than 48000 cars per 24 hours. The adjusted mean of the peak flow decreased by $0 \cdot 86 \%$ (95\% confidence interval $1.99 \%$ to $-0.28 \% ; \mathrm{p}=0.137)$ in the midexposure group and $2 \cdot 18 \%(3.30 \%$ to $1.04 \% ; \mathrm{p}<0.001)$ in the high exposure group compared with the low exposure group.

Table III shows the cumulative respiratory symptoms and odds ratios associated with an increase of 25000 cars in the school district adjusted as described in the methods. A small increase in odds ratio was observed for respiratory infections at the date of examination, the lifetime prevalence of croup, recurrent wheezing, and recurrent dyspnoea. There were no significant changes in the prevalence of asthma, recurrent bronchitis, and hay fever.

To check for an effect of traffic on pulmonary symptoms in conditions of high exposure, measure-

TABLE I-General characteristics of 4678 German children living in Munich

\begin{tabular}{lcrc}
\hline Variable & Boys & \multicolumn{1}{c}{ Girls } & \multicolumn{1}{c}{ Total } \\
\hline No (\%) & $2275(48 \cdot 6)$ & $2403(51 \cdot 4)$ & $4678(100 \cdot 0)$ \\
Mean (SD) age (years) & $10 \cdot 2(0 \cdot 5)$ & $10 \cdot 2(0 \cdot 4)$ & $10 \cdot 2(0 \cdot 5)$ \\
Mean (SD) height (cm) & $143 \cdot 5(6 \cdot 2)$ & $142 \cdot 9(6 \cdot 6)$ & $143 \cdot 2(6.5)$ \\
Mean (SD) weight (kg) & $34 \cdot 8(6 \cdot 5)$ & $34 \cdot 4(6 \cdot 7)$ & $34 \cdot 6(6.6)$ \\
\hline
\end{tabular}

TABLE II-Percentage changes in measurements of pulmonary function associated with exposure of 25000 cars a day in school district in 4320 German children in Munich

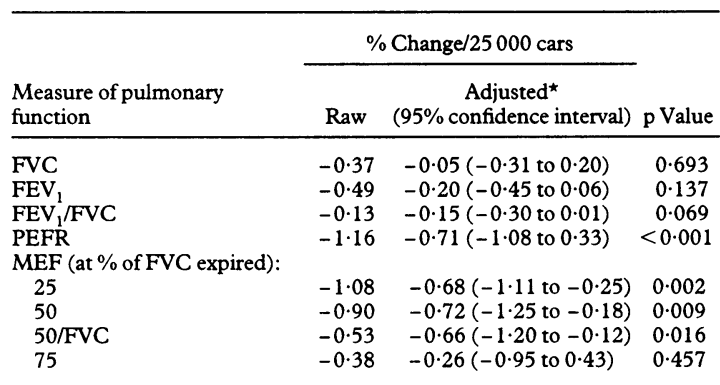

*Adjusted for sex, parental history of asthma, ln (height), ln (weight) month of examination, compliance with test, number of cigarettes smoked at home daily, and use of gas or coal for cooking or heating.

FVC= forced vital capacity; FEV 1 forced expiratory volume in one second; $\mathrm{FVC}=$ forced vital capacity; $\mathrm{FEV}_{1}$ forced expiratory volume in on
$\mathrm{PEFR}=$ = peak expiratory flow rate; $\mathrm{MEF}=$ maximal expiratory flow. ments were categorised into thirds as above. The adjusted odds ratio for recurrent dyspnoea increased to $1.04(0.76$ to $1.44 ; p=0.381)$ in the middle category of exposure and to $1.40(1.03$ to $1.91 ; p=0.046)$ in the highest category of exposure.

\section{Discussion}

We have shown an association between traffic load and reduced pulmonary function and increased respiratory symptoms in 10 year old children. Although there are inherent limitations of a cross sectional study, the results share considerable agreement with those from previous studies, in which measurements of pulmonary function were used as indicators of the effects of both indoor and outdoor air pollutants. ${ }^{21}{ }^{22}$ Our decrease in peak flow rates is comparable with the effect of passive smoking in the same population studied by Dold et al, in which the peak flow of children with parents who smoked was decreased by $2.5 \%(1.3 \%$ to $3.8 \% ; \mathrm{p}<0.001)$ compared with children with parents who did not smoke. ${ }^{23}$

\section{PREVIOUS STUDIES}

Most of the studies on air pollution have found that there is an association between the concentration of air pollutants and the decrease of pulmonary function in children. ${ }^{24} 25$ Whether air pollution assessed by traffic exposure has a measureable effect on human respiratory health has been examined in only a few epidemiological studies. Yokayama et al investigated housewives living next to main roads in Tokyo and found significantly more respiratory symptoms in those women who lived within 20 metres of the road than in those living further away. ${ }^{26}$ Murakami et al found up to twice as many more respiratory symptoms such as wheezing and severe colds in 4 to 11 year old children living next to a road than in children living further away. ${ }^{27}$ Ishizaki et al found symptoms of cedar pollinosis in $13 \cdot 2 \%$ of residents living within 200 metres of main intercity roads, compared with $9.6 \%$ of the total population examined..$^{28}$ None of these three studies, however, controlled for possible confounding factors such as age, sex, and smoking. These studies have been expanded on in a recent report by Nitta et al, who found odds ratios ranging from 0.76 to 2.75 for various airway symptoms in relation to the distance from the roadside. ${ }^{29}$

Several occupational studies have examined the effect of petrol and diesel exhaust fumes. Speizer and Ferris reported a slight association between exposure to car exhaust fumes in policemen and increased respiratory symptoms but not decreased pulmonary function. ${ }^{30}$ Evans et al described significantly lower forced expiratory volumes in one second and more respiratory symptoms in officers directing traffic in tunnels than those working on bridges. ${ }^{31}$ Ulfvarson and Alexandersson found a reduction in pulmonary function in stevedores on roll-on-roll-off ships who were exposed to diesel exhaust fumes from lorries during a work shift. ${ }^{32}$ After all the lorries were equipped with filters on the exhaust pipe the impairment in pulmonary function was reduced. Gamble et al examined men who worked in bus garages and found an apparent association between pulmonary function and length of employment. ${ }^{33}$ In contrast, a prospective cohort study by Ames et al of underground miners who were exposed to diesel emissions did not show any differences in respiratory function or chronic respiratory symptoms. ${ }^{34}$

\section{OUR STUDY}

The extent of change in pulmonary function and respiratory symptoms in our study is comparable with those found in previous studies on air pollution. We 
TABLE II-Cumulative respiratory symptoms and odds ratios associated with increase of 25000 cars a day in school district in 4678 German children in Munich

\begin{tabular}{|c|c|c|c|c|c|}
\hline \multirow[b]{2}{*}{ Respiratory symptom } & \multirow[b]{2}{*}{ Prevalence } & \multirow[b]{2}{*}{$\begin{array}{l}\text { Percentage } \\
\text { prevalence }\end{array}$} & \multicolumn{2}{|r|}{ Odds ratio/25 000 cars } & \multirow[b]{2}{*}{$\mathrm{p}$ Value } \\
\hline & & & Raw & $\begin{array}{l}\text { Adjusted }^{\star} \\
(95 \% \text { confidence interval) }\end{array}$ & \\
\hline Asthma & Lifetime & $8 \cdot 1$ & 1.06 & $1.06(0.97$ to 1.16$)$ & 0.180 \\
\hline Asthma & Presentinpastyear & $2 \cdot 7$ & 1.00 & $1.04(0.89$ to 1.21$)$ & $0 \cdot 160$ \\
\hline Croup & Lifetime & 10.5 & 1.08 & $1.09(1.00$ to 1.18$)$ & 0.044 \\
\hline Allergic rhinitis & Lifetime & 10.5 & 0.93 & $0.96(0.88$ to 1.05$)$ & 0.345 \\
\hline \multirow{3}{*}{$\begin{array}{l}\text { More than } 10 \text { upper } \\
\text { respiratory tract infections } \\
\text { Common cold }\end{array}$} & \multirow{3}{*}{$\begin{array}{l}\text { Presentinpastyear } \\
\text { Present at time of } \\
\text { examination }\end{array}$} & & & & \\
\hline & & 1.8 & 1.04 & $0.95(0.76$ to 1.19$)$ & 0.645 \\
\hline & & $6 \cdot 3$ & $1 \cdot 21$ & $1.20(1.08$ to 1.34$)$ & 0.001 \\
\hline Recurrent bronchitis & Lifetime & $18 \cdot 6$ & 1.03 & $1.05(0.98$ to 1.12$)$ & 0.172 \\
\hline Recurrent wheezing & Lifetime & 16.9 & 1.08 & $1.08(1.01$ to 1.16$)$ & 0.033 \\
\hline Recurrent dyspnoea & Lifetime & $8 \cdot 6$ & $1 \cdot 07$ & $1.10(1.00$ to 1.20$)$ & 0.039 \\
\hline Coughing & Lifetime & $20 \cdot 3$ & 1.06 & $1.06(0.99$ to 1.13$)$ & 0.093 \\
\hline
\end{tabular}

*Adjusted for sex, parental history of asthma, parental college education, number of people in household, use of gas or coal for cooking or heating, month of survey, number of cigarettes smoked at home, and person who filled in the questionnaire. synergistic action of all emitted substances. There could be multiple effects of different pollutants; or effects of other pollutants, such as $\mathrm{PM}_{10}$ particles, may have been missed if we had looked at only one pollutant. Unexpectedly, nitrogen dioxide did not increase with traffic count. This may be due to the volatile character of the compound and the distance from the point of measurement to the next road with heavy traffic. The correlations between the other markers were to be expected. Ozone decreased because of immediate chemical reduction with nitrogen monoxide. ${ }^{36}$

Continuous measurements of air pollution, which were not performed directly at the roadside, did not exceed national standards for air pollution. Our results, however, imply that even below these standards effects due to air pollution exist. ${ }^{73}$ Otherwise, the conclusion would be either that the effective peaks are smoothed out by 24 hour averages or that the position of the measuring device is critical.

The observed effects probably reflect a direct relation between car traffic exhaust fumes and adverse effects on respiratory health. Because increased respiratory symptoms are reported as well, the observed reduction in pulmonary function is unlikely to reflect changes only within the physiological range. ${ }^{38}$ The mechanism by which air pollution acts on pulmonary physiology is still a matter of speculation..$^{39}$ As there was no significant increase in the prevalence of asthma and the response to cold air challenge, one could speculate that traffic exhausts promote primarily non-specific bronchial inflammatory symptoms but not bronchial hyperreactivity.

We cannot say whether the observed changes were permanent or reversible. To what extent such exposure leads to chronic disease should be studied. Nevertheless, protecting children from the risks of pollutants from car exhaust fumes is a major challenge.

We thank M Sund and D W Dockery for helpful comments, $\mathrm{F}$ Lynch and $\mathrm{M}$ Kohn for correcting the manuscript, $M$ Herrmann for digitalising the school district map, and W Bründl and W Mücke for providing data on air pollution. We also thank W Lehmacher, E Stiepel, R Frentzel-BeymeBauer, B Berbig, and $\mathrm{K}$ Winter for planning and conducting the study; G Röll for statistical advice; A Hillebrecht, K Beck, S Braun, A Fuger, A Becker, W Bialas, C Griehl, $\mathrm{H}$ Hörnlein, J Kohle, $\mathrm{H}$ Kroker, and $\mathrm{G}$ Lindl-Agiopolus for examining the children; $C$ Malin, $M$ von Mutius, T Kreyssig, A Provelegios, R Berbig, and A Jensen for providing trnsport; E Kienle for technical help; and C Bremer, J Rohe, S Funk, A Stankiewicz, L Pritscher, and M Molette de Morangier for typing data. We thank all of the head teachers, school secretaries, and class teachers who participated in the project. Finally, we thank all the parents and children who took part.

The Munich survey on asthma and allergy was supported by a grant from the Bayerische Staatsministerium für Landesentwicklung und Umweltfragen.

1 Arossa W, Spinaci S, Bugiani M, Natale P, Bucca C, de Candussio G. Changes in lung function of children after an air pollution decrease. Arch Environ Health 1987;42:170-4.

2 Charpin D, Kleisbauer JP, Fondari J, Graland B, Viala A, Gouenzo F. Respiratory symptoms and air pollution changes in children: the Gardanne coal-basin study. Arch Environ Health 1988;43:22-7.

3 Higgins ITT, d'Arcy JB, Gibbons DI, Avol EL, Gross KB. Effect of exposures to ambient ozone on ventilatory lung function in children. $A m$ Rev Respir Dis 1990;141:1136-46.

4 Ware JH, Ferris BG Jr, Dockery DW, Spengler JD, Stram DO, Speizer FE. Effects of ambient sulfur oxides and suspended particles on respiratory Effects of ambient sulfur oxides and suspended particles on respir

5 Goren AI, Brenner S, Hellmann S. Cross-sectional health study in polluted and nonpolluted agricultural settlements in Israel. Environ Res 1988;46:107-19.

6 Vedal S, Schenker MB, Munoz A, Samet JM, Batterman S, Speizer FE. Daily Vedal S, Schenker MB, Munoz A, Samet JM, Batterman S, Speizer FE. Daily
air pollution effects on children's respiratory symptoms and peak expiratory flow. Am ₹ Public Health 1987;77:694-8.

7 Neas LM, Dockery DW, Ware JH, Spengler JD, Speizer FE, Ferris BG Association of indoor nitrogen dioxide with respiratory symptoms an pulmonary function in children. Am $\mathcal{F}$ Epidemiol 1991;134:204-19.

8 Burchfield CM, Higgins MW, Keller JB, Howatt WF, Butler WJ, Higgin ITT. Passive smoking in childhood. Respiratory conditions and pulmonary function in Tecumseh, Michigan. Am Rev Respir Dis 1986;133:966-73.

9 Dekker C, Dales R, Bartlett S, Brunekreef B, Zwanenburg H. Childhood asthma and the indoor environment. Chest 1991;100:922-6. reported more often

These results support the argument that road traffic has adverse respiratory health effects 
10 Koenig JQ. Indoor and outdoor pollutants and the upper respiratory tract. f Allergy Clin Immunol 1988;81:1055-9.

11 Godlee F. Health and the environment-air pollution. II. Road traffic and modern industry. $B M 7$ 1991;303:1539-43.

12 Statistisches Landesamt der Landeshauptstadt München. Statistische Taschenbuch München 1990. Munich: Manz, 1990.

13 Umweltschutzreferat der Landeshauptstadt München. Umweltatlas Mïnchen. Munich: TUV Bayern, 1990

14 World Health Organisation. Air quality guidelines for Europe. Copenhagen: WHO, 1987 .

15 Bayerisches Landesamt für Umweltschutz. Belastungsgebiet München. 15 Bayerisches Landesamt für Um

Immissionskataster. Munich: BLfU, 1990. 16 TOV Bayern. Bericht über "Immissionsmessungen innerhalb der Stadtgrenze der Landeshauptstadt Mïnchen zur Vervollständigung des Immissionskatasters fir das gesamte Stadtgebiet. "Munich: TƯV Bayern, 1988.

17 Mutius E v, Dold S, Wist M, Stiepel E, Reitmeir P, Frentzel-Beyme-Bauer $R$ et al. Münchener Asthma- und Allergiestudie. Praevalenzen atopischer und asthmatischer Erkrankungen im Kindesalter in Bayern. Münchener Medizinische Wochenschrift 1991;133:675-9.

18 Nicolai $T$, Mutius von E, Reitmeir $P$, Wjst $M$. Reactivity to cold air hyperventilation in normal and asthmatic children in a survey of 5697 school children in Southern Bavaria. Am Rev Respir Dis 1993;147:565-72.

19 Ng'anga LW, Ernst P, Jaakkola MS, Gerardi G, Hanley JH, Becklage MR. Spirometric lung function. Distribution and determinants of test failure in young adult popultion. Am Rev Respir Dis 1992;145:48-52.

young adult popultion. Am Rev Respir Dis 1992;145:48-52. 20 SAS Institute. SAS user's guide: statistics. Version 6. Cary, North Carolina:
SAS Institute, 1989.

21 Samet JM. The epidemiologic approach to investigating indoor and outdoor air pollution. In: Gardner' DE, ed. Toxicology of the lung. New York: Raven 1933:311-34.

22 Bromberg PA. Asthma and automotive emissions. In: Watson AY, Bates RR, Kennedy D, eds. Air pollution, the automobile, and public health. Washington, DC: National Academy Press, 1988:465-98.

23 Dold S, Reitmeir P, Wjst M, von Mutius E. Auswirkungen des Passivrauchens auf den kindlichen Respirationstrakt. Monatsschrift fïr Kinderheilkunde 1992;140:763-8.

24 Wardlaw AJ. The role of air pollution in asthma. Clin Exp Allergy 1993;23: $81-96$

25 Romieu I, Lugo MC, Velasco RS, Sanchez S, Meneses F, Hernandez M.

Air pollution and school absenteeism among children in Mexico City. Am pollution and school absent

26 Yokoyama Y, Nitta H, Maeda K, Aoki S. What interaction does indoor nitrogen dioxide have on the effect of the automobile exhaust? Tokai $\mathcal{F}$ Exp Clin Med 1985;10:379-84.

27 Murakami M, Ono $M$, Tamura $\mathrm{K}$. Health problems of residents along heavy traffic roads. f Hum Ergol (Tokyo) 1990;19:101-6.

28 Ishizaki T, Koizumi K, Ikemori R, Ishiyama Y, Kushibiki E. Studies of prevalence of Japanese cedar pollinosis among the residents in a densely cultivated area. Ann Allergy 1987:58:265-70.

29 Nitta H, Sato T, Nakai S, Maeda K, Aoki S, Ono M. Respiratory health associated with exposure to automobile exhaust. 1. Results of

30 Speizer FE, Ferris BG. Exposure to automobile exhaust. I. Prevalence of 30 Speizer FE, Ferris BG. Exposure to automobile exhaust. I. Prevalence of respiratory symptoms and disease. II. Pulmonary function measurements. Arch Environ Health 1973;26:313-24.

31 Evans RG, Webb K, Homan S, Ayres SM. Cross sectional and longitudinal changes in pulmonary function associated with automobile pollution among bridge and tunnel officers. $A m \mathcal{F}$ Ind Med 1988;14:25-36.

32 Ulfvarson U, Alexandersson R. Reduction in adverse effect on pulmonary function after exposure to filtered diesel exhaust. Am f Ind Med 1990;17: $341-7$.

33 Gamble J, Jones W, Minshall S. Epidemiological-environmental study of diesel bus garage workers: acute effects of $\mathrm{NO}_{2}$ and respirable particulate on the respiratory system. Environ Res 1987;42.201-14.

34 Ames RG, Hall DS, Reger RB. Chroric respintory effects of exposure to diesel emissions in coal mines. Arch Environ Health 1984;39:389-94.

35 Sam PJ Aines. Arch Environ Healh 1984,39:389-94s of expoure to diesel

35 Sam

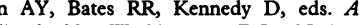
pollution, the automobile, Academy Press, 1988:77-97.

36 Atkinson R. Atmospheric transformation of automotive emissions. In: Watson AY, Bates RR, Kennedy D, eds. Air pollution, the automobile, and public health. Washington DC: National Academy Press, 1988:99-132.

37 Schwartz J. Air pollution and the duration of acute respiratory symptoms. Arch Environ Health 1992;47:116-22.

38 American Thoracic Society. Guidelines as to what constitutes an adverse respiratory health effect with special reference to epidemiologic studies of air pollution. Am Rev Respir Dis 1985;131:666-8.

39 Hoppenbrouwers T. Airways and air pollution in childhood: state of the art. Lung 1990;68(suppl):35-46.

40 Farley JM. Inhaled toxicants and airway hyperresponsiveness. Annual Review of Pharmacology and Toxicology 1992;32:67-88.

(Accepted 15 fune 1993)

\title{
Psychosocial predisposing factors for infantile colic
}

\author{
Päivi Rautava, Hans Helenius, Liisa Lehtonen
}

\section{Abstract}

Objective-To study associations between characteristics of families during the first pregnancy and after childbirth and the development of infantile colic.

Design-Randomised, stratified cluster sampling. Follow up from the first visit to a maternity health care clinic during pregnancy to three months after birth with confidential semistructured questionnaires.

Setting-Maternity health care clinics in primary health care centres in Finland.

Subjects-1443 nulliparous women and 1407 partners. Altogether 1333 women and 1279 men returned the questionnaires. When the infants were 3 months old 1208 women and 1115 men returned questionnaires.

Main outcome measures-Marital relationship; personal and social behaviour of parents during the pregnancy and their coping with the pregnancy; mothers' physical health and events, symptoms, and experiences in relation to pregnancy; self confidence and experiences of mothers and fathers in relation to childbirth; and parents' sociodemographic and educational variables. Measure of colic when the infant was 3 months old.

Results-Experience of stress and physical symptoms during the pregnancy, dissatisfaction with the sexual relationship, and negative experiences during childbirth were associated with the development of colic in the baby. None of the sociodemographic factors was associated with colic.

Conclusions-Early preventive health work during pregnancy should attempt to improve parents' tolerance of symptoms of stress and ability to cope and increase their confidence in parenting abilities.

\section{Introduction}

Infantile colic (three month colic) is described as a behavioural syndrome characterised by excessive crying, which is paroxysmal in nature, more likely to occur in the evenings, and without identifiable cause, during which an otherwise healthy infant between 2 weeks and 4 months of age is difficult to console. ${ }^{1}$ According to Wessel $e t a l$, a colicky infant is defined as a one who has paroxysms of irritability, fussing, or crying lasting for three hours a day for three days a week over three weeks. ${ }^{2}$

Most investigators have been concerned with gastrointestinal factors in the aetiology of colic: the immaturity of the gastrointestinal tract, ${ }^{3}$ type of feeding, ${ }^{46}$ intolerance to cows' milk, ${ }^{7}$ and lactose intolerance. ${ }^{89}$ The evidence, however, remains weak and contradictory, ${ }^{1}$ and there is an increasing tendency for research to implicate non-gastrointestinal factors. Neff postulated that because of an abnormal sensitivity of the central nervous system, minimal stimuli, which are usually without effect, may lead to the development of fussiness in certain infants. ${ }^{10}$ This theory is similar to that implicating the infants' own temperament. Carey correlated difficult temperament at 4 to 8 months of age with colic, but the relation between colic and temperament seems to be unclear as yet." ${ }^{11}$ The transfer of tension from mother to infant has been suggested to be a causative factor. ${ }^{12}$ Carey further confirmed this in a prospective study of 103 subjects. ${ }^{13}$ In a study by Paradise maternal emotional factors were not associated, but puerperal emotional tension or depression were. ${ }^{14}$

Infantile colic was described by Hewson $e t$ al as the end result of a complex transaction between infants and their environment, with many factors responsible for the crying and distress..$^{15}$ Any single study can 